\title{
AN EXPLORATION OF DISTRIBUTION CHANNELS: CHALLENGES AND OPPORTUNITIES FOR ORGANIC FOOD PRODUCERS IN CROATIA
}

\author{
Dušanka Gajdićn ${ }^{1}$ Kristina Petljak ${ }^{2}$, Željka Mesićc ${ }^{3}$ \\ *Corresponding authorE-mail:dgajdic@vguk.hr
}

\begin{abstract}
A R T I C L E I N F O
Original Article

Received: 29 November 2018

Accepted: 17 December2018

doi:10.5937/ekoPolj1804461G

UDC 339.188.2:631.147(438)
\end{abstract}

Keywords:

organic agriculture, organic food, organic food producers, distribution channels, Croatia.

JEL: Q13,Q01

\begin{abstract}
A B S T R A C T
Organic market in the EU is growing faster than the area of production and is facing many problems and challenges. In order to obtain more information of the structure and organizational features of the organic farms in the Republic of Croatia, as well as perceptions of organic food producers about barriers that disable faster development of organic food market, empirical research was conducted on the sample of 66 organic food producers. Research findings suggest that the largest number of organic farms are small farms up to 5 hectares (ha). Organic food producers are the most prominent in the field of fruit production, and key motives for engagement in organic agriculture are their personal beliefs, health reasons and environmental care. Regarding the distribution of the organic food products, most producers sell their organic food products directly to the final consumer, mostly on family farms and local fairs. Regarding indirect distribution, specialized stores are dominant retail format, followed by wholesale. The paper gives valuable contribution, as it lists the producers' proposals for further development of organic food products market in Croatia.
\end{abstract}

(C) 2018 EA. All rights reserved.

\section{Introduction}

At the global and European level, the trend of growth of organic production has been recorded. Since 2000, the surface of land for organic farming has grown by $400 \%$. Organic agriculture has been developing rapidly, and the available statistical data show that 2.7 million producers in 178 world countries practice organic agriculture

1 Dušanka Gajdić, Ph.D. candidate, Križevci College of Agriculture, M. Demerca 1, 48000 Križevci, Croatia, Phone: 0989555 369, E-mail: dgajdic@vguk.hr, ORCID ID orcid.org/0000-0002-4153-723X

2 Kristina Petljak, Ph.D., Assistant Professor, Department of Trade and International Business, Faculty of Economics \& Business Zagreb, University of Zagreb, Trg J.F.Kennedyja 6, 10000 Zagreb, Croatia, Phone: +385 12383 376, E-mail: kpetljak@efzg.hr, ORCID ID https://orcid.org/0000-0002-5785-1928

3 Željka Mesić, Ph.D., Department of Marketing in Agriculture, Faculty of Agriculture, University of Zagreb, Svetošimunska cesta 25, 10000 Zagreb, Croatia, Phone: +385 12393 641, E-mail: zmesic@ agr.hr, ORCID ID https://orcid.org/0000-0002-9349-1560

http://ea.bg.ac.rs 
(Willer and Lernoud, 2018) (Remark: data published in 2018 show the state in organic production in 2016). During 2016, 57.8 million hectares of organic agricultural land was recorded, where Australia leads with 27.1 million hectares.

Regarding Europe, the leader is Spain, followed by Italy, France and Germany. Italy takes the lead in the number of organic producers. Countries with the biggest organic food market in 2016 are the United States (38.9 billion EUR), then Germany ( 9.5 billion EUR), France (6.7 billion EUR) and China (5.9 billion EUR). The biggest share of the organic market in the entire market is in Denmark, then Luxembourg, Switzerland, Sweden and Austria. Organic product retail has grown globally from 2000 till 2016 by $460 \%$.

According to the available data on organic agriculture and the European market, the European organic production is well developed. In many European countries, market grows faster than the production and domestic supply cannot meet the demand. The analysts predict that organic food and beverage market in Europe could grow at a compound annual growth rate of about 7\% in income by 2020 (Technavio, 2016). The research conducted in three countries of the EU (Denmark, Italy and United Kingdom), concerning organic food consumption at its very peak, show that those three markets are at very different stages. In Denmark, organic market is very developed due to the existence of a broadly recognized official organic label and the fact that many organic food products are sold in supermarkets at relatively low prices. In Italy, the level of organic production is high, but domestic consumption is relatively low and most organic food products are exported. Besides that, most market transactions happen on local markets, where trust in farmers presents a guarantee to the consumers of the quality of the organic products, rather than the labelling scheme controlled by the government. In the United Kingdom, demand for organic raw materials has been rapidly growing. Distribution structure is similar to the Danish scheme in that the products are mainly sold in the supermarkets (Denver and Christensen, 2007).

From the position of the producers, some of the obstacles for the development of organic market are (Kottila, 2010; Vlahović et al., 2015; Koreleska, 2017): poorly developed and unorganized market, lack of cooperation and communication in the supply chain, lack of marketing knowledge and low prices of organic food products. In most EU countries, main distribution channels for the producers (processors) of organic food are (Hamzaoui-Essoussi and Zahaf, 2012; Dovleac, 2016; Enjolras and Aubert, 2018; Jarczok, 2018): direct sale, specialized organic food product stores and supermarkets.

In the Republic of Croatia, most farms that are involved in organic production are small family agricultural holdings (hrv. obiteljsko poljoprivredno gospodarstvo $O P G)$, that also face many challenges. The results of the research conducted by Petljak (2013) show that most farms are smaller than 5 hectares and fruit-growing is the most dominant branch. The producers pointed out their personal beliefs as the key motive for organic production.

Distribution channels in Croatia are mostly connected with the terms "local market", "alternative market", "direct sale" and "short supply chains" because most organic 
food products in Croatia are still sold by direct channels, and only a small percentage of domestic producers distributes their products through retail (Petljak, 2013). One of the major constraints for a further development of organic food market in Croatia is low farmers' ability to act independently on the market. In addition, the distribution within the organic food sector is quite inefficient. Despite growing interest for organic food market there is a lack of studies dealing with organic food distribution channel in developing countries, such as Croatia.

Considering the rapid growth of the organic food market and the mentioned challenges for producers, especially regarding distribution channels, the research questions $(R Q)$ which arise are the following:

RQ1: How are organic food product distribution channels organized?

RQ2: What are main structural and organizational features of organic family farms?

RQ3: What are the perceptions of organic food producers about barriers that disable faster development of organic food market?

\section{Theoretical background of the research}

\section{Organic agriculture characteristics and legislation in EU}

In European countries and in the rest of the world, different terms are used for organic agriculture. Besides the term "organic" (England) and "biological" (France, Italy, Netherlands and Portugal), the term "ecological" (Denmark, Sweden, Spain) is also used. In Germany, terms "ecological" and "biological" are most common (Blair, 2012). In the Republic of Croatia, the term organic agriculture is used. Over time, different authors have in different ways defined, or described organic agriculture. According to Znaor (1996), organic agriculture is a system of agricultural management that aims at ethically acceptable, ecologically clean, socially just and cost-effective agricultural production. Organic agriculture in production strives at the complete exclusion of the input that does not originate from agricultural holding, considering local conditions that require specific management systems. This is achieved through the use, where possible, of agronomic, biological and mechanical methods, against the use of synthetic matters, for performing specific functions inside the system (Renko and Bošnjak, 2009). Organic agriculture represents agriculture which is conceptualized in the way that it protects the soil, water, air, plants, animals and genetic resources, it is not degrading for the environment, it is technically appropriate, economically stable and socially acceptable (Kisić, 2014).

At the international level, general principles of organic agriculture are defined by two organizations: Codex alimentarius Commission FAO/WHO-a (Food and Agriculture Organization of the United Nation/World Health Organization) and International Foundation for Organic Agriculture - IFOAM, the roof organization with around 750 members in 108 countries (Znaor and Landau, 2014). According to the IFOAM definition, organic production is a production system that maintains the health of the soils, ecosystems and people and is based on ecological processes, bio diversity and cycles adjusted to the local conditions, and not on the use of input with side effects. 
Organic agriculture combines tradition, innovation and science to benefit mutual social environment and promotes fair relations and good quality of life for all who are engaged. Although there are many different definitions of organic agriculture, every definition includes ecology, care, health and fairness.

Organic agricultural farms are usually smaller, diversified and more extensive than the conventional ones. Organic farmers pay special attention to the protection of the environment, nature and animal welfare (Song Lee et al., 2015). Due to negative aspects of capital-intensive agriculture, in the sense of negative ecological, social and economic consequences caused by mass production, specialization, standardization of the product and high income, there has been an increased interest of the foreign and domestic scientific and general public for organic agriculture (Petljak, 2011). In recent decades, organic food has become very popular among the producers, retailers and consumers (Jones et al., 2001; Cerjak et al., 2010; Ham et al., 2018). The popularity of organic food is the result of many factors. The most important are: a lot of unfarmed land suitable for organic production, less contamination of the eco system, growing concern of the consumers for their health and increasing importance of renewable resources in the global environment (Renko and Bošnjak, 2009). Growing demand for organic food products whose production is not harmful for the environment is also one of the reasons of the expansion of organic agriculture (Rodale, 2010). However, the stated reasons are only starting points for a healthy organic agricultural development. The market is considered the key factor of organic agricultural development, where a farm, as an elementary unit on the organic food product market, meets a series of issues like: the legislative, education on the methods of organic agriculture and organic food production, higher costs and narrowed distribution channels (Renko and Bošnjak, 2009). At the beginning of organic agriculture development, ecological awareness was the key motive of production and consumption of organic food, but later, health reasons and evidence that organic food is closely related to the healthy lifestyle have appeared as the key motives (Götze et al., 2016).

The European Union (EU) legally regulated organic agriculture by adopting the regulation on organic agriculture and production in 1991 (EU Regulation no. 2092/91). In Croatia, organic agriculture was regulated by law in 2001, when the first Organic Production of Agricultural and Food Products Act (Official Gazette, 12/01) was passed, which was in line with the EU and IFOAM regulative. The new Organic Agriculture and Ecological Product Labelling Act (Official Gazette, 139/10) was adopted in 2010, and Organic Agricultural Production Regulation in 2016 (Official Gazette, 19/16). Organic agriculture has been identified as the key element in sustainable management of European natural resources. In line with that, the European Commission (EC) suggested a new draft of the organic legislative in 2018, with the aim of creating foundations for sustainable development of ecological production and its positive effects on the environment, and, in so doing, ensuring an efficient functioning of the internal market of organic products and fair market competition, which helps the farmers to earn fair income, ensures consumer trust, protects consumer interests and supports short 
distribution channels and local production (EU ORDINANCE 2018/848). Organic food production requires more resources (COGNIZANT, 2014), especially human resources. In addition, production depends on high seasonality and weather conditions, products are easily spoiled and require specific storage conditions. These features influence the high levels of insecurity and risk regarding market prices (which can be up to $30 \%$ higher) and ensuring the amounts for retailers. Consequently, access to the market is much more difficult, especially due to the competition with imported organic foods.

\section{Organic production in the Republic of Croatia}

Croatia records a significant trend of increasing the land with organic production (Figure 1). During 2016, 3,546 producers with the surface of 93.814 hectares were recorded, which makes $6.07 \%$ in relation to total agricultural surfaces (Ministry of Agriculture according to the data from the Croatian Bureau of Statistics, 2016). According to EUROSTAT, in 2017 there were approximately 4,023 organic producers, 357 refiners, 23 importers and 1 exporter of organic food products.

Figure 1. The share of agricultural surface with organic production in the total agricultural surface in the Republic of Croatia from 2010 to 2017 (in \%)

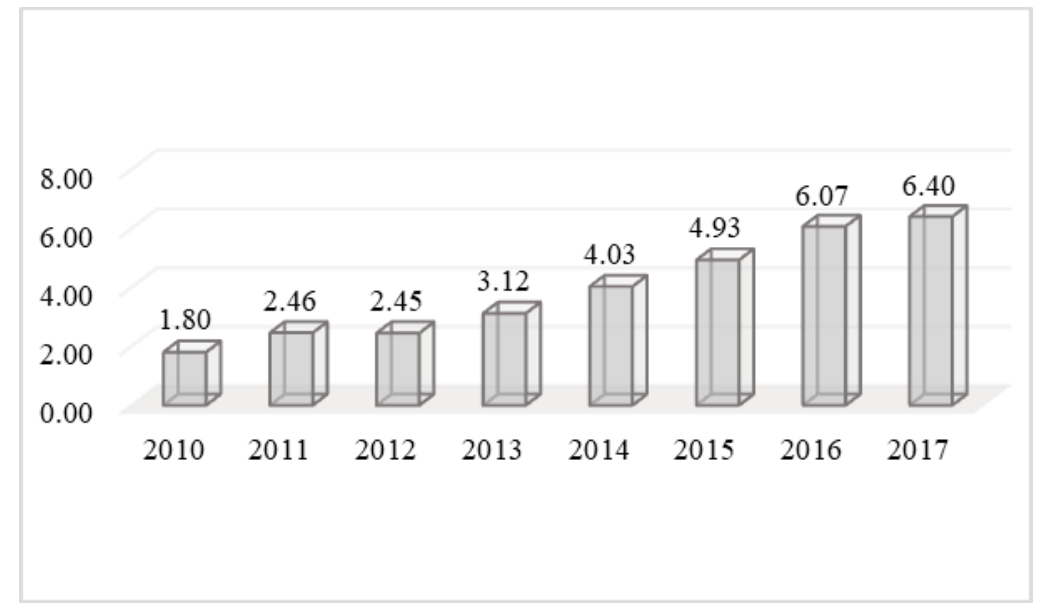

Source: authors, according to the Croatian Bureau of Statistics, 2016

Croatia applies all the regulations regarding organic food production and labelling, including the national label for organic food (Labelling of Food and Animal Feed in Organic Production Regulation, NN 25/11), however, certified organic food production in Croatia is considerably lower than in other EU member countries. Croatian organic product market is not well organized. There is a low offer of processed products due to limited processing capacities, and the consumers are not well informed (BrčićStipčević and Petljak, 2012). Croatian Ministry of Agriculture points out that the issue with the organic product market is the fact that fresh, organic products are mostly of domestic production, while organic processed products are mostly imported and can be found in specialized stores, healthy food stores and supermarkets. More than $50 \%$ of 
products are of foreign origin. Often, domestic supply cannot satisfy the demand and domestic chain stores that sell organic products offer a variety of imported products. Those imported products are mostly food that can be easily grown in Croatia, like beans, barley, buckwheat, herbal teas etc. Therefore, the term organic food comes into question if that food has to travel thousands of miles to reach the consumer.

\section{Characteristics of the organic food products market}

The production of organic food is facing many problems and challenges and cannot meet the fast growing organic market in the EU. From the producers' perspective, some of the main obstacles are (Kottila, 2010; Vlahović et al., 2015; Koreleska, 2017): poorly developed and unorganized market, lack of cooperation and communication in the supply chain, lack of marketing knowledge and low prices of organic food products. From the demand side of the supply chain, i.e. the consumers of organic products, according to Padel and Foster (2005), key issues are: limited availability of products, especially in supermarkets, high retail prices, consumers being insufficiently informed i.e. they are not familiar with organic food products or organic food labels. Renko and Bošnjak (2009) think that Croatian organic food producers have not adjusted their assortment and choice of location to the consumers, who point out that the greatest obstacle for buying organic food is not knowing where to buy them.

Many researchers and research studies have dealt with the issues of who the consumers are and what are their main reasons for buying organic food (Harper and Makatouni, 2002; Padel and Foster, 2005; Shaw Hughner et al., 2007; Cerjak et al., 2010: Żakowska, 2011; Dimitri and Dettmann, 2012; Rong-Da Liang, 2016; Kranjac et al., 2017; Hashem et al., 2018), while there are considerably fewer of those who study the issue from the position of the producer, i.e. distribution of organic products onto the market. mMost literature about organic food consumption has been recorded in the USA, followed by Great Britain, Italy, Germany and Greece (Hemmerling et al., 2015).

Several studies from earlier periods show that high prices of organic food products is one of the main reasons why organic consumption is still low (Magnusson et al., 2001; Shafie and Rennie, 2012; Götze et al., 2016). However, in the last decade, organic market of the EU has grown faster in relation to expansion of agricultural surfaces under organic production. The indicators of consumption and behaviour of organic food consumers are different. According to the research conducted in Croatia (Cagalj et al., 2016), consumers are ready to spend more for fruit and vegetables from organic production (apples, tomatoes), if there is proof of organic production and because of the belief in health benefits of organic food. The same support we get from the research results conducted in Sweden (Bosona and Gebresenbet, 2018).

In the research conducted by Rong-Da Liang (2016), consumer trust in organic food products and their effects on health have also had a considerable impact on the decision to buy organic products. Many other studies (Götze et al., 2016; Escobar-López et al., 2017; Hashem et al., 2018), confirm the fact that health, ecological acceptability and taste are 
important motives which encourage organic food production. Demand for organic food in the EU has been growing due to rising concern about negative external influences connected with the effects of intensive cultivation systems on human health and environment (Nasir and Karakaya, 2014). Basically, organic food consumption is strongly connected with social and ethical principles and beliefs. Consumers mostly describe organic food as food that is ecologically acceptable, has a positive effect on health and has good sensory quality, while the main disadvantages are high price and insufficient representation on the market.

In her research, Kottila investigated interaction between the participants in the organic food supply chain and established that information exchange and cooperation among the interested parties in the supply chain is mostly poor and the main participants, from producers to retailers do not have clear and common goals, especially in relation to the need of the consumers that buy organic products (Kottila and Rönni 2008; Kottila 2010). Research conducted by Bandara et al. (2017) examines conditions where partners (buyers and suppliers) cooperate in the supply chain, i.e. they interact in that partnership. Relation that is based on the power of an individual (the buyer) can influence the quality of the relation between the partners, and indirectly, it can influence operative results of the suppliers.

The study of Marques Vieira et al. (2013) investigates the role of wholesale and retail as mediators involved in organic supply chain. If organic food products are sold under the private label (PL), then most value is kept by the retailer. The retailer strategically connects organic food product with its reputation using the own private label. However, although the retailer invests in the promotion of the organic food private label, it still depends on organic food producers to fulfil consumer requirements. This suggests the partnership needs to be created among small producers and retail chains to satisfy the needs of the consumers. Furthermore, retail plays a key role in the development of this market by spreading information on the benefits of organic food consummation on the health of the consumers and for the establishment of a reliable base of suppliers. The results of the research made by Kottila (2009) show that there is a need for more horizontal cooperation among the actors specialized in organic food production, including the commercial, governmental and nongovernmental actors, which could contribute to a better understanding and development of knowledge in the added value of organic products. With the increased demand for organic food in the EU, this represents a strong incentive for creating special agreements between the producers and the retailers, development of private labels (Jonas and Roosen, 2005) and investments in the quality aspects.

Hamzaoui Essoussi and Zahaf 's research from 2008 shows that small communities tend to adhere to local producers of organic food for three main reasons: low availability of organic food in the supermarkets in small communities, greater trust of the consumers in local farmers than in supermarkets and direct marketing of food from the local supplier to the consumer. The authors think that modern distribution channels in small communities must be aware of different needs of the consumers compared to those in large cities. For example, the price does not influence their decision, but rather, it is the trust in the producer. 


\section{Organic food distribution channels}

The analysis of the domestic and foreign literature has shown that there is no unified definition of distribution channels for organic food products. According to BrčićStipčević et al. (2011), distribution channels of organic agricultural products can be divided into (1) direct distribution channels, (2) indirect distribution channels and (3) emerging distribution channels (Figure 2).

Figure 2. Organic food distribution channels
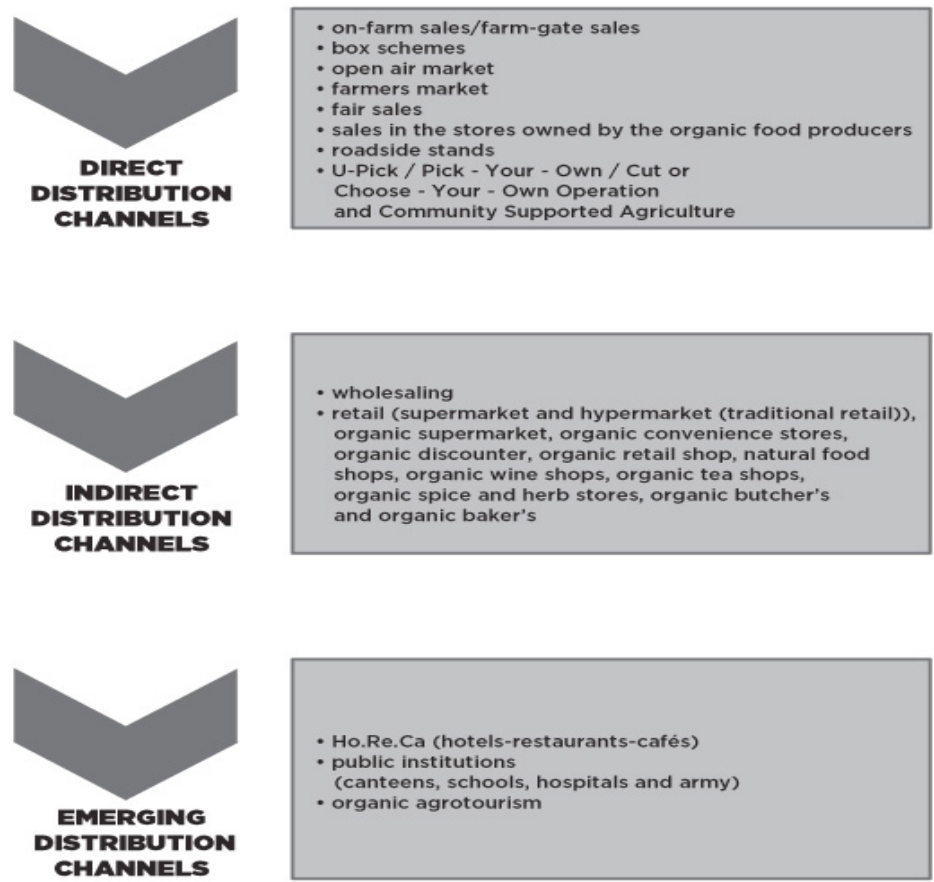

Source: authors, according to Brčić-Stipčević et al., 2011

Direct distribution refers to direct sale of organic food products to the consumers. Those distribution channels are: on-farm sales/farm-gate sales, box schemes, open air market, farmers market and fair sales, sales in the stores owned by the organic food producers (Brčić - Stipčević et al., 2011), roadside stands, U-Pick / Pick - Your - Own / Cut or Choose Your - Own Operation and Community Supported Agriculture (Brunch and Ernest, 2010).

Indirect distribution channels of organic food products in the Republic of Croatia are wholesaling and retail. Wholesalers buy organic food products from multiple producers and offer them to retail, i.e. to retailers and restaurateurs. Organic food product retail includes sales in different retail formats: supermarket and hypermarket (traditional retail), organic supermarket, organic convenience stores, organic discounter, and different specialised retails like small stores with the dominant assortment of organic food products: organic retail shop, natural food shops, organic wine shops, organic 
tea shops, organic spice and herb stores), organic butcher's and organic baker's (Brčić - Stipčević et al., 2011). Emerging distribution channels include Ho.Re.Ca (hotelsrestaurants-cafés) and public institutions (canteens, schools, hospitals and army), as well as the distribution of organic food via organic agrotourism (Petljak, 2013).

Most organic food producers sell their products in supermarkets (Willer and Lernoud, 2016), via direct sales, and in specialized stores. In the case study conducted by Sanders et al. (2016), among the analysed countries of the EU, in Italy, France and Germany there is up to $50 \%$ of organic food sold via specialized retail and direct sales. Opposite to that, in the Czech Republic, Denmark and the United Kingdom, more than 70\% of organic food is sold in supermarkets. Since in the last decade organic food production has been constantly growing, some questions arise: to what extent do organic food product supply chains function efficiently, do they share the common added value and the risks evenly among them, what effect do primarily small farms have on the primary producers and do they create and maintain the trust of the consumers. Lack of statistical and public data on the organic food market for specific products in the EU countries and in Croatia, especially information on the supply chains, is one of the factors that complicates the search for answers to all the above questions and also one of the reasons for conducting this research.

Principal actors of this chain are agricultural producers, food industry, distribution sector and retail sector. According to the data acquired from EUROSTAT and FiBLAMI and the overview of the existing scientific and expert literature, it can be concluded that organic food product markets differ considerably and have specific characteristics in every EU country; most organic food producers sell their products in supermarkets, directly as well as in specialized stores; integration and cooperation are important factors that can strengthen organic food supply chains, and the length of the supply chain and power relations among the participants are equally important as the type of the supply chain; produce like the fruit and vegetables dominate on the organic food markets in many EU countries, especially in Italy, Germany and France, as well as in Croatia, followed by dairy and few other processed products. Factors that can positively influence the development of high-quality organic food products are $(\mathrm{H}$. Essoussi and Zahaf, 2008; Kottila, 2009; Żakowska, 2011; Garner and Ayala, 2018; Bosona and Gebresenbet, 2018; Scalvedi and Saba, 2018) better availability of organic food products; good organization of the supply chain; better integration and cooperation among the members of the supply chain; good promotion and better information on the advantages of consummation of organic food products; wider range and differentiation of finished (processed) products. The factors that can negatively influence the quality of the organic food market are (Żakowska, 2011; Wägeli and Hamm, 2016; Götze et al., 2016; Scalvedi and Saba, 2018) insufficient domestic production and dependence on the import of processed products; inefficiency in the supply chain; lack of interest in different forms of connection and cooperation of all the actors in the supply chain; constant oscillations of prices, insufficient or inadequate facilities for storage and logistics; lack of marketing orientation. 


\section{Research on the distribution channels of organic food products in the Republic of Croatia}

\section{Research methodology}

The data for the research on the distribution channels of organic food products in the Republic of Croatia, due to the specificity of the research topic, have been gathered with different research methods - via an online survey, via phone calls and face-to-face conversations in the sales units (mostly in Zadar county). The survey comprised of altogether 27 questions structured in three parts. The first part related to the structural characteristics of the production unit with the questions about the size of the unit, locations of the production unit and the activities farmers perform. The second part dealt with the organizational features of the unit that are defined with the organization and methods of management, workforce organization, organization of the sales and other organizational activities, while the third part related to the suggestions for future market development. Email addresses of the organic food producers were found on the Ministry of Agriculture website, on the List of organic producers in 2015. Total of $n=66$ respondents participated in the research. Data collected by the survey were analysed with the use of the SPSS v.23.0 software. Univariate analysis was conducted to determine frequencies of producers' answers.

\section{Research results and discussion}

\section{Description of the sample}

The gender structure of the sample was $70.3 \%$ men and $29.7 \%$ women. The age structure of the sample slightly shifts to the older respondents; the most prevalent age groups in the sample are above 50 years old. Furthermore, over half of the respondents have completed secondary school (56.1\%), followed by high school (27.3\%). Table 1 shows socio-demographic characteristics of the sample.

Table 1. Socio-demographic characteristics of the sample

\begin{tabular}{|l|l|l|}
\hline \multicolumn{1}{|c|}{ (Total) } & & \multicolumn{1}{c|}{$\mathbf{~}$} \\
\hline \multirow{3}{*}{ Gender } & Male & 70.3 \\
\cline { 2 - 3 } & Female & 29.7 \\
\hline \multirow{4}{*}{ Age } & $21-30$ & 4.5 \\
\cline { 2 - 3 } & $31-40$ & 12.1 \\
\cline { 2 - 3 } & $41-50$ & 28.8 \\
\cline { 2 - 3 } & $51-60$ & 37.9 \\
\hline
\end{tabular}




\begin{tabular}{|l|l|l|}
\hline \multirow{4}{*}{ Education } & More than 60 & 16.7 \\
\cline { 2 - 3 } & Basic school & 1.5 \\
\cline { 2 - 3 } & Secondary school & 56.1 \\
\cline { 2 - 3 } & High school & 27.3 \\
\cline { 2 - 3 } & University degree & 15.2 \\
\hline
\end{tabular}

Source: empirical research

Most producers are registered as the producers - family agricultural units, manufacturers or joint-stock companies (67.7\%). 17 producers $(26.2 \%)$ are registered as mixed units for production and processing (Table 2).

Table 2. Type of the registered subject

\begin{tabular}{|l|l|l|}
\hline \multicolumn{1}{|c|}{ Type of the registered subject } & n & \multicolumn{1}{c|}{$\%$} \\
\hline A (registered producer; family farming (cro. OPG), manufacturing, joint-stock business) & 44 & 67.7 \\
\hline B (registered processors) & 1 & 1.5 \\
\hline C (registered importer) & 1 & 1.5 \\
\hline AB (mixed unit - production/processing) & 17 & 26.2 \\
\hline D (other forms of the registered units) & 2 & 31.0 \\
\hline Total & 66 & $100 \%$ \\
\hline
\end{tabular}

Source: empirical research

Most producers have up to five employees (78.5\%) per unit. A smaller number of producers $(16.9 \%)$ have 6 to 10 employees, and most production units are run exclusively by the family members. Only $4.6 \%$ of the units have more than 21 employees, which mostly includes seasonal workers and part-time employees.

Figure 3. Organic producers' surface under organic farming

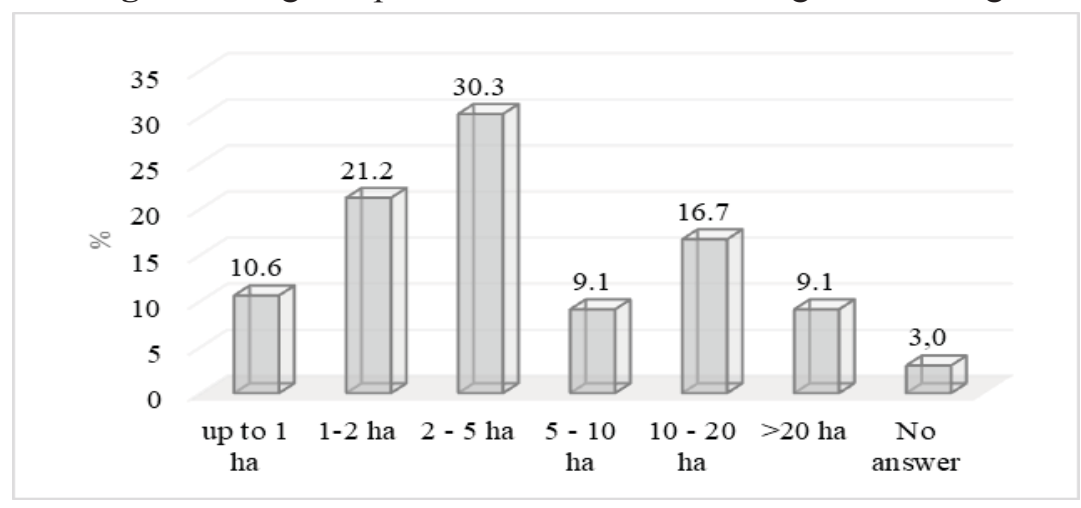

Source: empirical research 
According to the surface of organic production (Figure 3), the research shows that most dominant are the producers with the surface of up to 5 hectares $(62.1 \%)$, which is compatible with the data from many other countries in Southeast Europe. Most producers produce organic fruit $(n=36)$, vegetable $(n=20)$ and grow organic wine $(n=15)$. Few producers grow medical and herbal plants $(n=13)$, crop farming $(n=11)$, olive farming $(n=8)$ and beekeeping $(n=5)$.

In order to examine the statistically significant correlation between distribution channels and size of the surface under organic production, chi-square $\left(\chi^{2}\right)$ test was calculated (Table 3$)$. The obtained results $\left(\chi^{2}=13.422 ; \mathrm{p}>0.05\right)$ show that there is no statistically significant correlation between distribution channels and the surface of agricultural land under organic production, which furthermore implies the need of investigating factors which influence the decision making process when choosing distribution channel.

Table 3. Cross tabulation of agricultural land (in ha) under organic production and the distribution channels

\begin{tabular}{|l|c|c|c|}
\hline & $\begin{array}{c}\text { Direct sales } \\
\text { (n) }\end{array}$ & $\begin{array}{c}\text { Sales through intermediaries } \\
\text { (wholesale and/or retail) } \\
\text { (n) }\end{array}$ & $\begin{array}{c}\text { Direct sales and sales } \\
\text { through intermediaries } \\
\text { (n) }\end{array}$ \\
\hline up to 1 ha & 1 & 1 & 1 \\
\hline $\mathbf{1 - 2}$ ha & 8 & 1 & 0 \\
\hline $\mathbf{2}-\mathbf{5}$ ha & 9 & 0 & 7 \\
\hline $\mathbf{5 - 1 0}$ ha & 4 & 0 & 0 \\
\hline $\mathbf{1 0 - 2 0}$ ha & 7 & 1 & 2 \\
\hline more than $\mathbf{2 0}$ ha & 11 & 2 & 2 \\
\hline
\end{tabular}

$$
\chi^{2}=13.422 ; \mathrm{p}>0.05
$$

Source: empirical research

\section{Motives for organic production}

Key motives for organic production are primarily personal beliefs of producers $(n=16)$, then there health reasons $(n=11)$ and environmental care $(n=10)$. Producers see governmental incentives, friends' persuasion, unemployment and financial reasons as less motivating. Similar findings on the motives for organic production have been found in other researches (Kubala et al., 2008; Cranfield et al., 2010; Petljak, 2013; Vlahović et al., 2015).

\section{Distribution channels of the organic food producers in the Republic of Croatia}

Research results have indicated that $60.6 \%$ producers sell their organic food products directly to the final consumer, while $13.6 \%$ of them sell their products indirectly, via a mediator (wholesale, retail). Almost one fifth of the respondents use both channels of distribution equally $(19.6 \%)$. Only $6 \%$ of the producers sell their organic products via the Internet (Table 4). 
Table 4. Main distribution channels of organic food products

\begin{tabular}{|l|c|c|}
\hline \multicolumn{1}{|c|}{ Distribution channels } & $\mathbf{n}$ & $\mathbf{\%}$ \\
\hline direct sale to the consumers & 40 & 60.6 \\
\hline sales via mediators (wholesale, retail) & 9 & 13.6 \\
\hline equally market directly or via mediators & 13 & 19.7 \\
\hline Internet sale & 4 & 6.0 \\
\hline Total & $\mathbf{6 6}$ & $\mathbf{1 0 0}$ \\
\hline
\end{tabular}

Source: empirical research

Producers that sell their products directly to the final consumers were asked to list the distribution channels they use for placing their ogranic products on the market. 42 of them sell on the family farm, 29 on the fairs and fewest sell on the local markets $(n=15)$ and via home delivery $(n=12)$. Organic producers that distribute their products via indirect channels, do so mostly in specialized stores $(n=12)$, or to the wholsale buyer $(n=11)$. Smaller share of producers sell their products via groups of solidary exchange, convenience stores, agricultural cooperatives and restaurants.

To establish the attitudes of the organic food producers about organic food market organization, the respondents were asked to express the level of agreement/disagreement with certain statements on a Likert scale, where 5 represented complete agreement and 1 absolute disagreement. Based on the results displayed in Table 5, it can be concluded that most respondents agree that for further development of the organic food market, it is necessary to form partnerships (mean=4.10; $\mathrm{SD}=1,185)$.

Table 5. Producers' attitudes on organic food market organization

\begin{tabular}{|l|c|c|}
\hline \multicolumn{1}{|c|}{ Statements } & Mean & SD \\
\hline $\begin{array}{l}\text { For a serious distribution of organic food on the market, it is necessary } \\
\text { to form partnerships among the domestic organic food producers, due } \\
\text { to insufficient number of individual organic food products. }\end{array}$ & 4.10 & 1.185 \\
\hline $\begin{array}{l}\text { I manage to sell organic food products regardless of the way how I } \\
\text { distribute them on the market. }\end{array}$ & 3.81 & 1.180 \\
\hline $\begin{array}{l}\text { I would produce more organic food products, if I had a secure buyer; } \\
\text { dependable distribution channels. }\end{array}$ & 3.79 & 1.457 \\
\hline $\begin{array}{l}\text { I sell my products at the farm to avoid high costs of distribution to } \\
\text { final consumers. }\end{array}$ & 3.22 & 1.33 \\
\hline
\end{tabular}

Source: empirical research 
Organic producers'suggestions for further development of organic food market in the Republic of Croatia

According to the respondents' opinions, further development of organic food production in Croatia should lie on the following factors (Figure 4): more promotion of the Croatian organic food product label $(\mathrm{n}=18)$, more information on organic products for consumers $(\mathrm{n}=14)$, more cooperation among organic producers $(\mathrm{n}=10)$ and more responsibility from relevant institutions (Ministry of Agriculture) in terms of prompt payment of subsidies $(\mathrm{n}=8)$.

Figure 4. Producers' suggestions to the Ministry of Agriculture

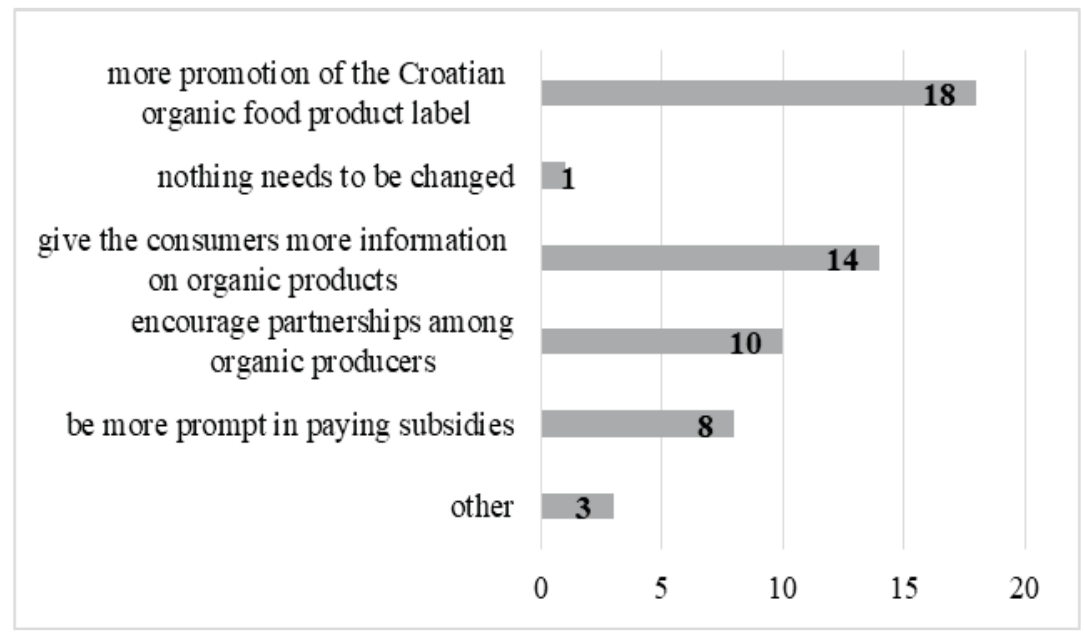

Source: empirical research

Respondents think that for further development of organic food market in Croatia, domestic producers should expand the offer of the processed products while small organic producers must be encouraged to join larger producer's organizations to gain power when negotiating with the retailers. In addition producers need to be encouraged to produce more fruit and vegetable and lower the prices of organic products (Figure 5). 
Figure 5. Producers' suggestions for future development of organic food market in the Republic of Croatia

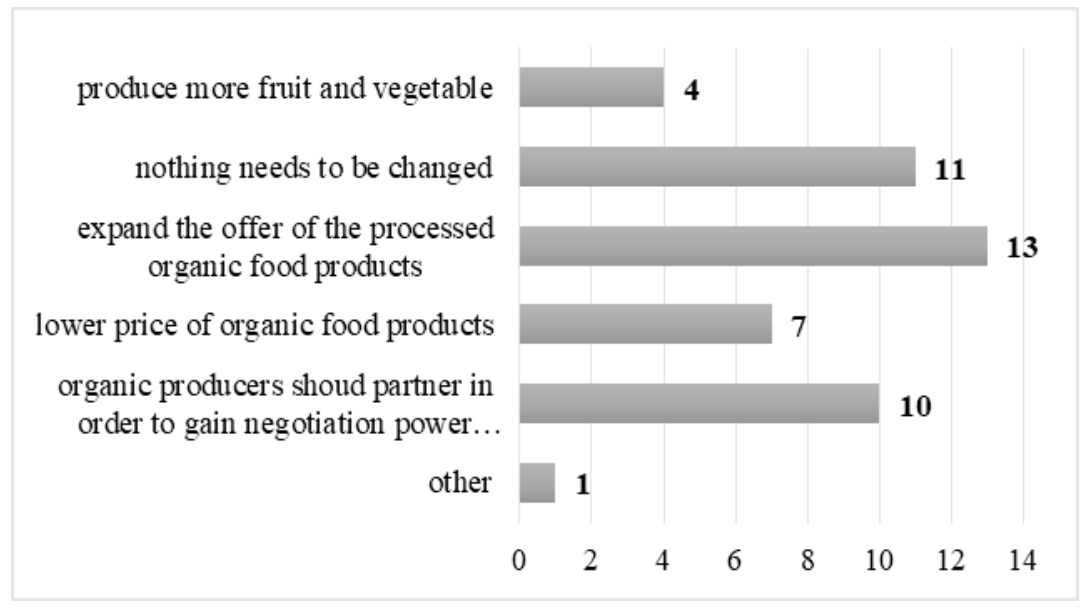

Source: empirical research

Respondents think that for future development of organic food product market in Croatia, food retailers should (Figure 6): encourage cooperation among the domestic producers, influence the price policy, educate and inform the consumers more and expand the offer of organic products. In order to improve cooperation and communication of organic food producers with other stakeholders in supply chain, they need to build a relationship based on mutual trust and commitment. Similarly, but on the example of traditional food products, the study by Mesić et al. (2018) revealed that relationship based on trust, commitment, economic satisfaction, good reputation and low level of coercive power and conflict have a positive influence on the supply chain performance.

Figure 6. Producers' suggestions for future development of organic food market in the Republic of Croatia - retailers' perspective

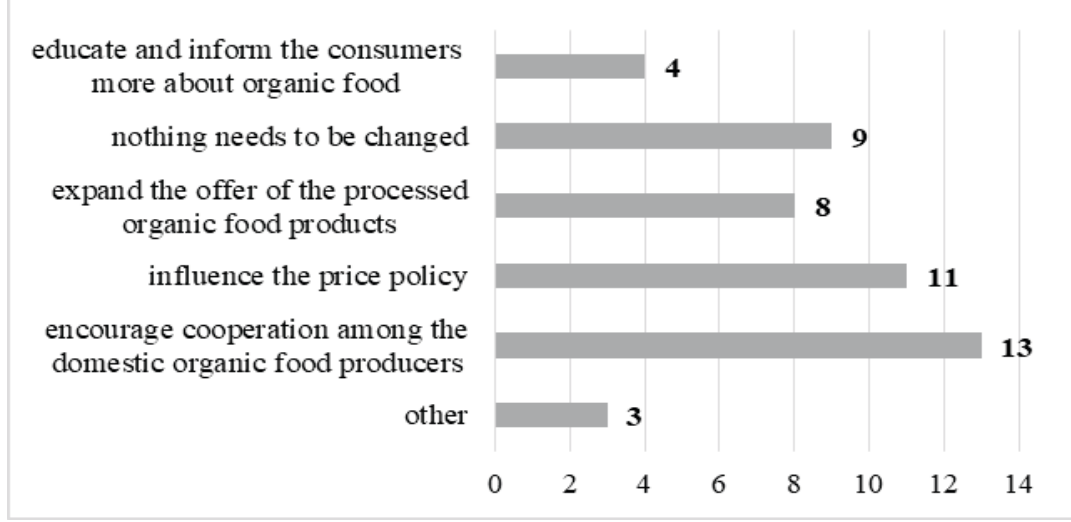

Source: empirical research 
$76.2 \%$ of respondents see rising demand and a significant progress of organic food production in the future, and only $4.8 \%$ think that the demand will be falling. The rest of the respondents predict that the offer and demand will remain the same as now.

\section{Limitations and recommendations for future research}

Considering the results of the research, one should bear in mind the existing research limitations. First limitation refers to the research sample. Although the survey was sent to a larger number of addresses of organic producers, only a small number of organic food producers participated in the research. That kind of sample creates a partial picture of the state of organic food agriculture, especially of organic food distribution channels. Further research should be based on a qualitative examination of the producers via face to face interviews.

\section{Conclusions}

The choice of the distribution channel is of great importance, especially for small organic food producers. Organic producers can choose among direct channels of distribution, like ordering a green box, groups of solidary exchange, farm-gate selling or selling in their own stores, and indirect distribution channels, the so-called modern retail like the supermarkets, specialized healthy food stores, restaurants and other mediators. All of the above-mentioned forms of distribution brings certain advantages and disadvantages, and the choice of distribution channels should be based on the size of the farming unit, particularity production, the level of development and the location. Also, especially for small farms, it would be good to maintain the connection with the final consumer that can support local agriculture, short dustribution channel in particular.

In order to gain a clear picture of the distribution channels of organic food products in the Republic of Croatia, the research among the Croatian organic food producers was conducted. The findings suggest that most organic farm lands are smaller than 5 ha. Out of the activities organic producers practice the most, fruit farming is most represented, and the main motive for organic farming are personal beliefs. The organic food producers distribute their products mostly directly, through selling at the farm. The reason for that is big distrust and insecurity, as well as discrepancies in the law and regulations of the Republic of Croatia, where large producers are in a considerably more dominant position than the smaller ones.

There is a small percentage of those who market their organic food products via indirect channels in specialized stores and with the buyers - wholesalers. The respondents answered the question about the actions needed for further market development. Domestic organic producers pointed out that education and informing the consumers are areas which need most attention from the Ministry of Agriculture. In addition, they deem partnerships among the domestic producers necessary, in order to gain power in negotiating with retail chains and state. Furthermore, for future market development, there is also a need for encouraging cooperation between the leading food chain retailers and the producers. Domestic producers should form and join associations in order to 
negotiate with the supermarkets, while the leading supermarket chains should initiate cooperation with the domestic producers of organic food.

The results of the conducted research can be applied for scientific and practical purposes. It is therefore at disposal to organic food producers and retailers, aiming at better understanding and achieving the desired channels of distribution. The findings can also serve as the guidelines for the Ministry of Agriculture, while analysing the future of organic agriculture in the Republic of Croatia. The goal is to develop organic agriculture because it is Croatia's partner for sustainable future.

\section{Conflict of interests}

The authors declare no conflict of interest.

\section{References}

1. Bandara, S., Leckie, C., Lobo, A., \& Hewege, C. (2017). Power and relationship quality in supply chains: The case of the Australian organic fruit and vegetable industry, Asia Pacific Journal of Marketing and Logistics, 29(3), 501-518., https://doi.org/10.1108/APJML-09-2016-0165

2. Blair, R. (2012). Organic Production and Food Quality: A Down to Earth Analysis, A John Wiley \& Sons, Ltd., Iowa

3. Bosona, T., \& Gebresenbet, G. (2018). Swedish Consumers' Perception of Food Quality and Sustainability in Relation to Organic Food Production, Foods, 7(4), 1-17., https://doi.org/10.3390/foods 7040054

4. Brčić-Stipčević, V., Petljak, K., \& Guszak, I. (2011). Distribution channels and characteristics of organic food market, Proceedings of $11^{\text {th }}$ International Scientific Conference „,Business Logistics in Modern Management“, Faculty of Economics in Osijek, 111-125. Retrieved from http://blmm-conference. com/wp-content/uploads/BLMM_2011.pdf [in Croatian: Brčić-Stipčević, V., Petljak, K., \& Guszak, I. (2011). Kanali distribucije i obilježja tržišta ekoloških prehrambenih proizvoda, Zbornikradova 11. znanstvenog skupa s međunarodnim sudjelovanjem „,Poslovna logistika u suvremenom menadžmentu“, Ekonomski fakultet Osijek, 111-125. Preuzeto sa: http://blmm-conference.com/wp-content/ uploads/BLMM_2011.pdf]

5. Brčić-Stipčević, V., \& Petljak, K. (2012). Research in organic food purchase in Croatia, Tržište, 23(2), 189-207.

6. Brunch, M. L., \& Ernest M. D. (2010). Choosing Direct Marketing Channels for Agricultural Products, The University of Tennessee, Institute of Agriculture

7. Cagalj, M., Haas, R., \& Morawetz, U.B. (2016). Effects of quality claims on willingness to pay for organic food: Evidence from experimental auctions in Croatia, British Food Journal, 118(9), 2218-2233., https://doi.org/10.1108/BFJ-11-2015-0453

8. Cerjak, M., Mesić, Ž., Kopić, M., Kovačić, D., \& Markovina, J. (2010). What motivates consumers to buy organic food: Comparison of Croatia, Bosnia Herzegovina, and Slovenia, Journal of Food Products Marketing, 16(3), 278292., https://doi.org/10.1080/10454446.2010.484745 
9. COGNIZANT (2014). Supply Chain Management of Locally-Grown Organic Food: A Leap Toward Sustainable Development, Retrieved from: https:/www. cognizant.com/whitepapers/Supply-Chain-Management-of-Locally-GrownOrganic-Food-A-Leap-Toward-Sustainable-Development-codex928.pdf

10. Cranfield, J., Henson, S., \& Holliday, J. (2010). The motives, benefits, and problems of conversion to organic production, Journal of the Agriculture, Food, and Human Values Society, 27(3), 291-306., DOI 10.1007/s10460-009-9222-9

11. Croatian Bureau of Statistics (2016): Organic farming, Retrieved from https://www. dzs.hr/Hrv_Eng/publication/2017/01-01-19_01_2017.htm (November 5, 2018)

12. Denver, S., \& Christensen, B. T. (2007). Organic consumption in three European countries, 3rd QLIF Congress, Hohenheim, Germany, March 20-23, Retrieved from http://orgprints.org/view/projects/int_conf_qlif2007.html

13. Dimitri, C., L., \& Dettmann, R. (2012). Organic food consumers: what do we really know about them?, British Food Journal, 114(8), 1157-1183., https://doi. org/10.1108/00070701211252101

14. Dovleac, L., (2016). An overview on the supply chain for European organic food market, Bulletin of the Transilvania University of Braşov, 9(58), 325-330.

15. Enjolras, G. \& Aubert, M. (2018). Short food supply chains and the issue of sustainability: a case study of French fruit producers, International Journal of Retail \& Distribution Management, 46(2), 194-209, https://doi.org/10.1108/ IJRDM-08-2016-0132

16. Escobar-López, S.Y., Espinoza-Ortega, A., Vizcarra-Bordi, I., \& Thomé-Ortiz, H. (2017). The consumer of food products in organic markets of central Mexico, British Food Journal, 119(3), 558-574., https://doi.org/10.1108/BFJ-07-2016-0321

17. Eurostat (2018). Organic Farming Statistics, Retrieved from https://ec.europa. eu/eurostat/statisticsexplained/index.php/Organic_farming_statistics (November 5, 2018)

18. FiBL (2018). Organic Farming Statistics, Retrieved from https://www.fibl.org/ en/themes/organic-farming-statistics.html (November 5, 2018)

19. Garner, B., \& Ayala, C. (2018). Consumer supply-chain demands and challenges at farmers' markets, British Food Journal, 120(12), 2734-2747., https:/doi. org/10.1108/BFJ-03-2018-0154

20. Götze, F., Mann, S., Ferjani, A., Kohler, A., \& Heckelei, T. (2016). Explaining market shares of organic food: evidence from Swiss household data, British Food Journal, 118(4), 931-945., https://doi.org/10.1108/BFJ-09-2015-0318

21. Ham, M., Pap, A., \& Stanic, M. (2018). What drives organic food purchasing?evidence from Croatia, British Food Journal, 120(4), 734-748., https://doi. org/10.1108/BFJ-02-2017-0090

22. Hamzaoui Essoussi, L., \& Zahaf, M. (2008). Decision making process of community organic food consumers: an exploratory study, Journal of Consumer Marketing, 25(2), 95-104., https://doi.org/10.1108/073637608 10858837 
23. Hamzaoui-Essoussi L. \& Zahaf, M. (2012). The Organic Food Market: Opportunities and Challenges, Organic Food and Agriculture - New Trends and Developments in the Social Sciences, Matthew Reed (Ed.), 63-82., InTech, Rijeka, Retrieved from: http://www.intechopen.com/books/organic-foodandagriculture-new-trends-and-developments-in-the-social-sciences/theorganic-food-market-opportunities-andchallenges

24. Harper, G. C., \& Makatouni, A. (2002). Consumer perception of organic food production and farm animal welfare, British Food Journal, 104(3/4/5), 287 299., https://doi.org/10.1108/00070700210425723

25. Hashem, S., Migliore, G., Schifani, G., Schimmenti, E., \& Padel, S. (2018). Motives for buying local, organic food through English box schemes, British Food Journal, 120(7), 1600-1614., https://doi.org/10.1108/BFJ-08-2017-0426

26. Hemmerling, S., Hamm, U., \& Spiller, A. (2015). Consumption behaviour regarding organic food from a marketing perspective - a literature review, Organic Agriculture, 5(4), 277-313., DOI 10.1007/s13165-015-0109-3

27. IFOAM (2005). Definition of organic agriculture, Retrieved from: https:// www.ifoam.bio/en/organic-landmarks/definition-organic-agriculture

28. IFOAM EU GROUP (2016). Organic in Europe, prospects and developments 2016, Retrieved from https://www.ifoameu.org/sites/default/files/ifoameu organic_in_europe_2016.pdf

29. Jarczok-Guzy, M. (2018). Obstacles to the development of the organic food market in Poland and the possible directions of growth, Food Science \& Nutrition, 6(6), 1462-1472. Retrieved from https://doi.org/10.1002/fsn3.704

30. Jonas, A., \& Roosen, J. (2005). Private labels for premium products - the example of organic food, International Journal of Retail \& Distribution Management, 33(8), 636-653., https://doi.org/10.1108/09590550510608412

31. Jones, P., Clarke $\square$ Hill, C., Shears, P., \& Hillier, D. (2001). Retailing organic foods, British Food Journal, 103(5), 358-365., https://doi.org/ 10.1108/00070700110396358

32. Kisić, I. (2014). Uvod u ekološku poljoprivredu, Agronomski fakultet sveučilišta u Zagrebu, Zagreb

33. Koreleska, E. (2017). Production and market of ecological product in Poland, Proceedings of the $8^{\text {th }}$ International Scientific Conference Rural Development Kaunas, Lithuania, 1119-1123., http://doi.org/ 10.15544/RD.2017.043

34. Kottila, M.R., \& Rönni, P. (2008). Collaboration and trust in two organic food chains, British Food Journal, 110(4/5), 376-394., https:// doi. org/10.1108/00070700810868915

35. Kottila, M.R. (2009). Knowledge sharing in organic food supply chains, Journal on Chain and Network Science, 9(2), 133-144., Retrieved from https:// www.wageningenacademic.com/doi/pdf/10.3920/JCNS2009.x168

36. Kottila, M.R. (2010). Understanding the organic chain - The framework of the interaction between actors in organic chains in relation to the ecological modernisation of food production, doctoral thesis, Faculty of Agriculture and Forestry of the University of Helsinki 
37. Kranjac, M., Vapa-Tankosić, J., \& Knežević, M. (2017). Profile of organic food consumers, Economics of Agriculture, 2, 497-513.

38. Kubala, J., Grodzińska-Jurczak, M., Cichoń, M., \& Nieszporek, K. (2008). Motivations for organic farming among farmers from Malopolska Province, Poland, International Journal of Environment and Sustainable Development, 7(3), 345-361., DOI: 10.1504/IJESD.2008.021904

39. Magnusson, M.K., Arvola, A., Koivisto Hursti, U.K., Åberg, L., \& Sjödén, P.O. (2001). Attitudes towards organic foods among Swedish consumers, British Food Journal, 103(3), 209-227., https://doi.org/10.1108/000707001103 86755

40. Marques Vieira, L., Marcia Dutra De Barcellos, Hoppe, A., \& Bitencourt da Silva, S. (2013). An analysis of value in an organic food supply chain, British Food Journal, 115(10), 1454-1472., https://doi.org/10.1108/BFJ-06-2011-0160

41. Mesić, Ž., Molnár, A. \& Cerjak, M. (2018). Assessment of traditional food supply chain performance using triadic approach: the role of relationships quality, Supply Chain Management: An International Journal, 23(5), 396-411., https://doi.org/10.1108/SCM-10-2017-0336

42. Nasir, V. A., \& Karakaya, F. (2014). Consumer segments in organic foods market, Journal of Consumer Marketing, 31(4), 263-277., http://dx.doi. org/10.1108/JCM-01-2014-0845

43. Padel, S., \& Foster, C. (2005). Exploring the gap between attitudes and behaviour: Understanding why consumers buy or do not buy organic food, British Food Journal, 107(8), 606-625., https://doi.org/10.1108/000707005106 11002

44. Petljak, K. (2011). Pregled razvoja i obilježja ekološke poljoprivrede u Republici Hrvatskoj, Ekonomski vjesnik: Review of Contemporary Entrepreneurship, Business, and Economic, 24(2), 382-395., Retrieved from https://hrcak. srce.hr/76191 [in Croatian: Petljak, K. (2011). Review of development and characteristics of organic agriculture in Croatia, Ekonomski vjesnik: Review of Contemporary Entrepreneurship, Business, and Economic, 24(2), 382-395., Retrieved from https://hrcak.srce.hr/76191]

45. Petljak, K. (2013). Distribution channels of organic food in the Republic of Croatia, Poslovna izvrsnost, 7(1), 73-97., Retrieved from https://hrcak.srce.hr/ index.php? show $=$ toc\&id_broj $=8617$

46. Ordinance on labelling of food and feed in organic production, NN 25/11, Retrieved from https://narodne-novine.nn.hr/clanci/sluzbeni/2011_02_25 _ 522.html

47. Renko, S., \& Bošnjak, K. (2009). Aktualno stanje i perspektive budućeg razvoja tržišta ekološke hrane u Hrvatskoj, Ekonomski pregled, 60(7-8), 369395. Retrieved from https://hrcak.srce.hr/40483

48. Rong-Da Liang, (2016). Predicting intentions to purchase organic food: the moderating effects of organic food prices, British Food Journal, 118(1), 183 199., https://doi.org/10.1108/BFJ-06-2015-0215

49. Rodale, M. (2010). Organic Manifesto: How organic farming can heal our planet, feed the world, and keep us safe, Rodale Inc., New York: 
50. Sanders, J., Gambelli, D., Lernoud, J., Orsini, S., Padel, S., Stolze, M., Willer, H., \& Zanoli, R. (2016). Distribution of the added value of the organic food chain, Braunschweig: Thünen Institute of Farm Economics, Final Report, $E K$, Retrieved from https://publications.europa.eu/en/publication-detail/-/ publication/a911740b-4cbe-11e7-a5ca-01aa75ed71a1/language-en/formatPDF

51. Scalvedi, M..L., \& Saba, A. (2018). Exploring local and organic food consumption in a holistic sustainability view, British Food Journal, 120(4), 749-762., https://doi.org/10.1108/BFJ-03-2017-0141

52. Shafie, F.A., \& Rennie, D. (2012). Consumer perceptions towards organic food, Procedia - Social and Behavioral Sciences, 49, 360-367., https://doi. org/10.1016/j.sbspro.2012.07.034

53. Shaw Hughner, R., McDonagh, P., Prothero, A., Shultz II, C.J., \& Stanton, J. (2007). Who Are Organic Food Consumers? A Compilation and Review of Why People Purchase Organic Food, Journal of Consumer Behaviour, 6(2-3), 94-110., https://doi.org/10.1002/cb.210

54. Song Lee, K., Chan Choe, Y., \& Hee Park, S. (2015). Measuring the environmental effects of organic farming: A meta-analysis of structural variables in empirical research, Journal of Environmental Management, 162, 263-274., https://doi. org/10.1016/j.jenvman.2015.07.021

55. Technavio (2016). Organic Food and Beverages Market in Europe 20162020, Research report, Retrieved from https:/www.technavio.com/report/ europe-non-alcoholic-beverages-organic-food-and-beverages-marketeurope-2016-2020

56. REGULATION (EU) 2018/848 OF THE EUROPEAN PARLIAMENT AND OF THE COUNCIL of 30 May 2018 on organic production and labelling of organic products and repealing Council Regulation (EC) No 834/2007, Retrieved from https://eur-lex.europa.eu/legal-content/HR/TXT/?uri=CELEX:32018R0848

57. Vlahović, B., Puškarić, A., \& Šojić, S. (2015). Research into Agricultural Producers' Motives for Engaging in Organic Production in the Republic of Serbia, Economic Insights - Trends and Challenges, 4(67), 31-39., Retrieved from http:// www.upg-bulletin-se.ro/archive/2015-2/4.Vlahovic_Puskaric_Sojic.pdf

58. Znaor, D. (1996.). Ekološka poljoprivreda-poljoprivreda sutrašnjice, Nakladni zavod Globus, Zagreb

59. Znaor, D., \& Landau, S.C. (2014). Unlocking the future - Seeds of Change: Sustainable Agriculture as a Path to Prosperity for the Western Balkans, Heinrich Böll Stiftung, Seth C. Landau, Zagreb, Retrieved from http://etnar. net/wp-content/uploads/2014/03/seedsofchange.pdf

60. Żakowska-Biemans, S. (2011). Polish consumer food choices and beliefs about organic food, British Food Journal, 113(1), 122-137., https:/doi. org/10.1108/00070701111097385

61. Wägeli, S., \& Hamm, U. (2016). Consumers' perception and expectations of local organic food supply chains, Organic Agriculture, 6(3), 215-224., DOI: 10.1007/s13165-015-0130-6 
62. Willer, H., \& Lernoud, J. (2016). The World of Organic Agriculture, Statistics and Emerging Trends 2016, Research Institute of Organic Agriculture (FiBL), Frick and IFOAM - Organics International, Retrieved from https://www. organic-world.net/yearbook/yearbook-2016.html

63. Willer, H., \& Lernoud, J. (2018). The World of Organic Agriculture, Statistics and Emerging Trends 2018, Research Institute of Organic Agriculture (FiBL), Frick and IFOAM - Organics International, Retrieved from https:/www. organic-world.net/yearbook/yearbook-2018.html 